\title{
Possible Enzymatic Downregulation of the Natriuretic Peptide System in Patients with Reduced Systolic Function and Heart Failure: A Pilot Study
}

\author{
Syed S. Zaidi, ${ }^{1}$ Ryan D. Ward, ${ }^{1}$ Kodangudi Ramanathan, ${ }^{1,2}$ Xinhua Yu, ${ }^{3}$ \\ Inna P. Gladysheva $\mathbb{D}^{1},{ }^{1,4}$ and Guy L. Reed $\mathbb{D}^{1,4}$ \\ ${ }^{1}$ Department of Medicine, University of Tennessee Health Science Center, College of Medicine, 956 Court Ave, \\ Memphis, TN 38163, USA \\ ${ }^{2}$ Veterans Administration Medical Center, Memphis, TN 38163, USA \\ ${ }^{3}$ School of Public Health, University of Memphis, Memphis, TN 38152, USA \\ ${ }^{4}$ Department of Medicine, University of Arizona, College of Medicine-Phoenix, Phoenix, Arizona, USA
}

Correspondence should be addressed to Guy L. Reed; guyreed@email.arizona.edu

Received 17 February 2018; Revised 28 May 2018; Accepted 27 June 2018; Published 26 July 2018

Academic Editor: Takeshi Kitai

Copyright (C) 2018 Syed S. Zaidi et al. This is an open access article distributed under the Creative Commons Attribution License, which permits unrestricted use, distribution, and reproduction in any medium, provided the original work is properly cited.

\begin{abstract}
Background. In patients with reduced systolic function, the natriuretic peptide system affects heart failure (HF) progression, but the expression of key activating (corin) and degrading enzymes (neprilysin) is not well understood. Methods and Results. This pilot study $(\mathrm{n}=48)$ compared plasma levels of corin, neprilysin, ANP, BNP, and cGMP in control patients with normal ejection fractions (mean EF $63 \pm 3 \%$ ) versus patients with systolic dysfunction, with (EF $24 \pm 8 \%$ ) and without (EF $27 \pm 7 \%$ ) decompensated HF (dHF), as defined by Framingham and BNP criteria. Mean ages, use of beta blockers, and ACE-inhibitors-angiotensin receptor blockers were similar between the groups. Corin levels were depressed in systolic dysfunction patients $(797 \pm 346 \mathrm{pg} / \mathrm{ml}) \mathrm{versus}$ controls $(1188 \pm 549, p<0.02)$, but levels were not affected by dHF $(p=0.77)$. In contrast, levels of neprilysin ( $<<0.01)$, cGMP $(\mathrm{p}<0.001)$, and ANP $(\mathrm{p}<0.001)$ were higher in systolic dysfunction patients than controls and were the highest in patients with dHF. Conclusions. Levels of neprilysin, ANP, BNP, and cGMP increased in patients with reduced systolic function and were the highest in dHF patients. Conversely, corin levels were low in patients with reduced EF with or without dHF. This pattern suggests possible enzymatic downregulation of natriuretic peptide activity in patients with reduced EF, which may have diagnostic and prognostic implications.
\end{abstract}

\section{Introduction}

The natriuretic peptide system plays a central role in heart failure (HF) and members of this pathway are the target for therapeutic (neprilysin) and diagnostic (ANP, BNP) strategies. The natriuretic peptide system is controlled in part by enzymes such as neprilysin (membrane metalloendopeptidase, neutral endopeptidase) and corin, a transmembrane serine protease expressed by cardiomyocytes. Neprilysin cleaves and inactivates natriuretic peptides and promotes HF [1]. In contrast, corin activates pronatriuretic peptides and opposes the development of experimental HF [2-6].
Corin and neprilysin can be released from the cell surface into circulation and detected in plasma or serum like many other membrane-bound proteases $[3,7,8]$. Plasma corin levels are reduced in patients with decompensated (d) HF with reduced (r) ejection fraction (EF) leading to diminished pronatriuretic peptide activation $[7,9]$. Recent experimental data suggests that corin cardiac expression and plasma levels may reflect the severity of cardiomyopathy and impaired systolic function and precede the development of dHF [2]. In this pilot study, we examined whether corin and neprilysin plasma levels are altered by the presence of reduced systolic function in patients with and without dHF. 


\section{Material and Methods}

2.1. Study Design. The study protocol and consent form were approved by the IRB of the Memphis VA Medical. All participants gave written informed consent to participate in the study. The investigation conforms with the principles outlined in the Declaration of Helsinki 1964. In this prospective study, patients (ages 50-70) admitted to the medical services or from the HF clinic were eligible for the study if they provided informed consent. Clinical data and samples were collected from 3 groups of patients: no HF and normal $\mathrm{EF}$ (nEF), no $\mathrm{HF}$ and systolic dysfunction ( $\mathrm{rEF} \leq 50 \%)$, and $\mathrm{HF}$ with systolic dysfunction $(\mathrm{rEF} \leq 50 \%)$. Clinical $\mathrm{dHF}$ was defined by abbreviated Framingham criteria using a HF scoring system that scores the presence of orthopnea, paroxysmal nocturnal dyspnea, exercise tolerance, sinus tachycardia, jugular venous pressure, hepatojugular reflex, third heart sound, basal crackles, hepatomegaly, and peripheral edema and by the presence of a BNP $>400 \mathrm{pg} / \mathrm{ml}[10,11]$. Consistent with these criteria, patients with clinical dHF had a sore of two or more. All patients had an echocardiogram or other measurement of their ejection fraction (EF) done within 60 days of enrollment.

A detailed medical history was obtained from the patient. Other pertinent clinical data were obtained from the computerized patient record system. Patients were excluded who had conditions that might independently affect the natriuretic system such as chronic kidney disease (estimated glomerular filtration rate $<60 \mathrm{ml} / \mathrm{min} / 1.73 \mathrm{~m}^{2}$ ), pulmonary hypertension (pulmonary artery pressure $>55 \mathrm{mmHg}$ by transthoracic echocardiography), myocardial infarction within the last 6 weeks, critical valvular heart disease, metastatic or terminal cancer, morbid obesity (BMI > 35), and cardiopulmonary support.

2.2. Blood Sample Collection. Venous blood samples were collected using standard EDTA-aprotinin tubes and immediately stored in ice. The blood samples were centrifuged at $3000 \mathrm{xg}$ for $20 \mathrm{~min}$ at $4^{\circ} \mathrm{C}$ and plasma aliquots were stored at $-80^{\circ} \mathrm{C}$ until analysis [7].

2.3. Heart Failure Biomarkers Measurement. ANP was measured by an enzyme immunoassays (ELISA) using antibodies against the $\mathrm{N}$-terminal sequence (Phoenix Pharm, Inc.). Corin levels were measured in plasma as we have described using DuoSet ELISA development assay (R\&D Systems.) [7]. cGMP and neprilysin were measured in plasma by ELISA according to the manufacturer's protocols (R\&D Systems, Thermo-Fisher Scientific). Other clinical chemistries were measured by the standard clinical laboratory methods in the hospital.

2.4. Statistical Analysis. The sample size was selected based on our previous study to provide $>90 \%$ statistical power to detect a simultaneous difference in corin, ANP, cGMP, and neprilysin levels between patients with $\mathrm{nEF}$ and patients with $\mathrm{rEF}$ and with or without dHF [7]. Unless otherwise indicated, continuous data are presented in tabular form or in box plots indicating the medians with upper and lower quartile values. Normally distributed data were analyzed by Student's $t$-test. Corin data were subjected to a square root transformation based on Box-Cox methodology. Multivariate regression was performed to examine whether other variables affect the association between corin and EF. A two-tailed $p$ value $<0.05$ was considered statistically significant.

\section{Results and Discussion}

Three patient groups were enrolled from the Memphis VA medical service or HF clinic: controls with normal $\mathrm{EF}$ (nEF, $\geq 50 \%$ ) and no $\mathrm{dHF}$ and reduced $\mathrm{EF}(\mathrm{rEF}<50 \%)$ with and without dHF. DHF was prospectively defined by Framingham criteria for objective signs of fluid retention using a standardized scoring system (see Table 1 of ref. [10]) and by a $\mathrm{BNP}>400 \mathrm{pg} / \mathrm{ml}$. The demographic information for each group is shown in Table 1. All patients were male, reflecting the composition of the VA. There were no significant differences in average age (59-61 years) among the three groups. The proportion of African-Americans was significantly higher in the $\mathrm{rEF}+\mathrm{dHF}$ patients than controls ( $81 \%$ versus $31 \%, \mathrm{p}<0.05)$ or than rEF patients $(25 \%)$. The mean BMI for all groups was in the overweight category, but it was lower in the $\mathrm{rEF}+\mathrm{dHF}$ group than in the control or rEF patients. A history of coronary artery disease was more common in control patients $(56 \%, \mathrm{p}<0.05)$ or rEF patients $(63 \%, \mathrm{p}<0.05)$ than in those with $\mathrm{rEF}+\mathrm{dHF}(13 \%)$. A history of hyperlipidemia was more common in patients with $\mathrm{rEF}$ than those with $\mathrm{rEF}+\mathrm{dHF}(\mathrm{p}<0.05)$. There were no significant differences between the groups in the frequency of other existing medical conditions (Table 1).

The laboratory data for each group is shown in Table 2. Triglycerides and albumin were significantly lower in patients with $\mathrm{rEF}+\mathrm{dHF}$ as compared with rEF patients, while alkaline phosphatase and total bilirubin were significantly higher indicating liver dysfunction, which is frequent at HF [12]. Total cholesterol was lower and total bilirubin was higher in $\mathrm{rEF}+\mathrm{dHF}$ patients than in controls.

The mean EFs $( \pm S D)$ in controls were $63 \pm 3 \%$. Among subjects with rEFs, there was no significant difference between those with $\mathrm{rEF}$ alone (EF $27 \pm 7 \%$ ) and those with $\mathrm{rEF}+\mathrm{dHF}$ (EF $24 \pm 8 \%$ ). Patients with $\mathrm{rEF}+\mathrm{dHF}$ differed from control patients in nearly every echocardiographic parameter (Table 3). Mean LV dimensions (LVIDd =6.2, LVIDs $=5.4 \mathrm{~cm}$ ) were larger in the rEF groups versus controls $(p<0.001)$, but there were no significant differences between the $\mathrm{rEF}$ and $\mathrm{rEF}+\mathrm{dHF}$ groups $(\mathrm{p}=0.88-0.92)$. There were no significant differences in left ventricular mass between the controls $(225 \pm 82 \mathrm{~g}), \mathrm{rEF}(343 \pm 213 \mathrm{~g})$, or $\mathrm{rEF}+\mathrm{dHF}(290 \pm 180 \mathrm{~g}$; $\mathrm{p}=0.27)$.

Radiographic evidence of HF was present in $88 \%$ of patients with $\mathrm{rEF}+\mathrm{dHF}$, but this was not seen in the other groups. Most patients with rEF were prescribed beta blockers and ACE-I/ARBs (Table 4); the frequency did not significantly differ between the $\mathrm{rEF}, \mathrm{rEF}+\mathrm{dHF}$, and control groups. Diuretic use was more common in patients with $\mathrm{rEF}+\mathrm{dHF}$ than $\mathrm{rEF}$ patients ( $88 \%$ versus $56 \%, \mathrm{p} \leq 0.05)$ and it was 
TABle 1: Patient characteristics.

\begin{tabular}{|c|c|c|c|}
\hline \multirow{2}{*}{ Patient Characteristics } & \multirow{2}{*}{$\begin{array}{c}\text { Normal Systolic Function } \\
\text { Control }\end{array}$} & \multicolumn{2}{|c|}{ Reduced Systolic Function (Systolic Dysfunction) } \\
\hline & & No Heart Failure & Heart Failure \\
\hline Male (N, (\%)) & $16(100)$ & $16(100)$ & $16(100)$ \\
\hline Black Race (N, (\%)) & $5(31)$ & $4(25)$ & $13(81)$ \\
\hline Age, yrs $($ mean \pm SD) & $59.3 \pm 6.8$ & $61.2 \pm 4.4$ & $59.6 \pm 4.2$ \\
\hline $\mathrm{BMI}($ mean $\pm \mathrm{SD})$ & $28.8 \pm 2.6$ & $28.4 \pm 3.4$ & $25.6 \pm 5.1^{\S, \dagger}$ \\
\hline Heart Failure Score $($ mean \pm SD) & $0.0 \pm 0.1$ & $0.8 \pm 0.4^{\ddagger}$ & $4.8 \pm 1.0^{\S, \dagger}$ \\
\hline \multicolumn{4}{|l|}{ Medical History } \\
\hline Coronary Artery Disease (N, (\%)) & $9(56)^{\S}$ & $10(63)^{\dagger}$ & $3(19)$ \\
\hline Myocardial Infarction (N, (\%)) & $2(13)$ & $2(13)$ & $0(0)$ \\
\hline Hypertension (N, (\%)) & $15(94)$ & $13(81)$ & $15(94)$ \\
\hline Diabetes Mellitus (N, (\%)) & $6(38)$ & $8(51)$ & $9(56)$ \\
\hline Cancer $(\mathrm{N},(\%))$ & $2(13)$ & $0(0)$ & $0(0)$ \\
\hline Cirrhosis (N, (\%)) & $0(0)$ & $0(0)$ & $0(0)$ \\
\hline Pulmonary Embolism (N, (\%)) & $0(0)$ & $0(0)$ & $1(6)$ \\
\hline Obstructive Sleep Apnea (N, (\%)) & $3(19)$ & $0(0)$ & $2(13)$ \\
\hline Arrhythmia (N, (\%)) & $1(6)$ & $5(31)$ & $4(25)$ \\
\hline Ethanol Consumption (N, (\%)) & $1(6)$ & $2(13)$ & $4(25)$ \\
\hline Chronic Obstructive Lung Disease (N, (\%)) & $2(13)$ & $2(13)$ & $5(31)$ \\
\hline Hyperlipidemia (N, (\%)) & $10(67)$ & $15(94)^{\dagger}$ & $7(44)$ \\
\hline
\end{tabular}

$p<0.05 ;{ }^{\circledR}$ reduced systolic function $+\mathrm{dHF}$ versus control, ${ }^{\dagger}$ reduced systolic function + dHF versus reduced systolic function no heart failure, and ${ }^{\ddagger}$ reduced systolic function versus normal systolic function.

TABLE 2: Laboratory results.

\begin{tabular}{|c|c|c|c|}
\hline \multirow{2}{*}{ Laboratory Test } & \multirow{2}{*}{$\begin{array}{l}\text { Normal Systolic Function } \\
\text { Control }\end{array}$} & \multicolumn{2}{|c|}{ Reduced Systolic Function (Systolic Dysfunction) } \\
\hline & & No Heart Failure & Heart Failure \\
\hline BUN (mg/dL) & $16 \pm 5$ & $19 \pm 6$ & $22 \pm 9^{\S}$ \\
\hline Creatinine $(\mathrm{mg} / \mathrm{dL})$ & $1.0 \pm 0.2$ & $1.1 \pm 0.2$ & $1.1 \pm 0.2$ \\
\hline $\mathrm{eGFR}\left(\mathrm{mL} / \mathrm{min} / 1.73 \mathrm{~m}^{2}\right)$ & $92 \pm 22$ & $78 \pm 19$ & $89 \pm 29$ \\
\hline Sodium $(\mathrm{mEq} / \mathrm{L})$ & $140 \pm 3$ & $139 \pm 4$ & $138 \pm 4$ \\
\hline Chloride (mEq/L) & $103 \pm 4$ & $102 \pm 3$ & $101 \pm 5$ \\
\hline Bicarbonate $(\mathrm{mEq} / \mathrm{L})$ & $27 \pm 4$ & $29 \pm 4$ & $28 \pm 5$ \\
\hline Leukocytes $\left(\mathrm{x} 10^{3} / \mathrm{mm}^{3}\right)$ & $5.8 \pm 1.3$ & $7.0 \pm 2.2$ & $7.4 \pm 3.1$ \\
\hline Hemoglobin (g/dL) & $12.5 \pm 1.5$ & $12.7 \pm 1.3$ & $12.1 \pm 1.8$ \\
\hline Hematocrit (\%) & $37 \pm 5$ & $38 \pm 4$ & $38 \pm 5$ \\
\hline Triglycerides (mg/dL) & $139 \pm 54$ & $173 \pm 79$ & $95 \pm 46^{\dagger}$ \\
\hline Total Cholesterol (mg/dL) & $169 \pm 32$ & $154 \pm 43$ & $128 \pm 37^{\S}$ \\
\hline $\mathrm{HDL}(\mathrm{mg} / \mathrm{dL})$ & $41 \pm 21$ & $38 \pm 8$ & $33 \pm 14$ \\
\hline $\mathrm{LDL}(\mathrm{mg} / \mathrm{dL})$ & $101 \pm 28$ & $82 \pm 40$ & $78 \pm 29$ \\
\hline AST (U/L) & $45 \pm 40$ & $38 \pm 12$ & $50 \pm 23$ \\
\hline $\operatorname{ALT}(\mathrm{U} / \mathrm{L})$ & $38 \pm 22$ & $33 \pm 15$ & $37 \pm 19$ \\
\hline Alkaline Phosphatase (U/L) & $94 \pm 41$ & $89 \pm 21$ & $130 \pm 56^{\dagger}$ \\
\hline Total Bilirubin (mg/dL) & $0.6 \pm 0.7$ & $0.6 \pm 0.4$ & $1.3 \pm 0.8^{\S, \dagger}$ \\
\hline Albumin $(\mathrm{g} / \mathrm{dL})$ & $3.9 \pm 0.5$ & $4.2 \pm 0.3$ & $3.6 \pm 0.6^{\dagger}$ \\
\hline
\end{tabular}

$p<0.05 ;{ }^{\circledR} \mathrm{rEF}+\mathrm{HF}$ versus control, ${ }^{\dagger} \mathrm{rEF}+\mathrm{HF}$ versus $\mathrm{rEF}$, and ${ }^{\ddagger} \mathrm{rEF}$ versus control. Data represent means $\pm \mathrm{SD}$ unless otherwise indicated.

also more frequent in $\mathrm{rEF}+\mathrm{dHF}$ patients than in control patients $(88 \%$ versus $38 \%, \mathrm{p}<0.01)$. Spironolactone, the only mineralocorticoid antagonist used, was significantly more common in patients with $\mathrm{rEF}(56 \%, \mathrm{p}<0.01)$ and $\mathrm{rEF}+\mathrm{dHF}$ $(50 \%, \mathrm{p}<0.05)$, than in control patients $(13 \%)$. Similarly, digoxin use was more common in patients with $\mathrm{rEF}(31 \%$, $\mathrm{p}<0.05)$ than in control patients $(0 \%, \mathrm{p}<0.05)$. Statin use was more common in patients with $\mathrm{nEF}$ or $\mathrm{rEF}$ than in patients with $\mathrm{rEF}+\mathrm{dHF}(\mathrm{p}<0.05)$.

ELISA was used to measure corin, N-ANP, neprilysin, and cGMP levels in plasma samples collected in EDTAaprotinin tubes to prevent coagulation and proteolysis. The 
TABLE 3: Echocardiography parameters.

\begin{tabular}{lccc}
\hline Laboratory Test & Normal Systolic Function (nEF) & \multicolumn{2}{c}{ Reduced Systolic Function (rEF) } \\
& Control & No Heart Failure & Heart Failure \\
\hline LVIDs, cm & $3.3 \pm 0.8$ & $5.4 \pm 1.2^{\ddagger}$ & $5.4 \pm 0.9^{\S}$ \\
LVIDd, cm & $4.8 \pm 0.8$ & $6.2 \pm 1.0^{\ddagger}$ & $6.2 \pm 0.7^{\S}$ \\
Left Atrium, cm & $3.8 \pm 0.4$ & $3.9 \pm 1.1$ & $4.3 \pm 0.5^{\S}$ \\
Ejection Fraction, \% & $63 \pm 3$ & $27 \pm 7^{\ddagger}$ & $24 \pm 8^{\S}$ \\
IVSd, cm & $1.1 \pm 0.2$ & $1.0 \pm 0.2$ & $1.0 \pm 0.3$ \\
AoRoot, cm & $3.7 \pm 0.3$ & $3.4 \pm 0.4$ & $3.3 \pm 0.5^{\S}$ \\
LVOT, cm & $2.0 \pm 0.1$ & $1.9 \pm 0.1$ & $2.1 \pm 0.1^{\dagger}$ \\
LVPWd, cm & $1.1 \pm 0.2$ & $1.0 \pm 0.1$ & $1.0 \pm 0.3$ \\
FS, \% & $32.7 \pm 7.9$ & $14.9 \pm 6.0^{\ddagger}$ & $13.4 \pm 6.3^{\S}$ \\
LVM, g & $225 \pm 82$ & $37 \pm 213$ & $290 \pm 180$ \\
RVSP, mmHg & $26 \pm 10$ & $7(58)^{\ddagger}$ & $44 \pm 4^{\S}$ \\
RVWM Abnormality N, (\%) & $0(0)$ & $9\left(75^{\ddagger}\right.$ & $5(36)^{\S}$ \\
LVWM Abnormality N, (\%) & $0(0)$ & $4(25)$ & $11(79)^{\S}$ \\
RV Size Abnormal N, (\%) & $0(0)$ & $11(73)$ & $9(60)^{\S}$ \\
RV Function Abnormal N, (\%) & $15(100)$ & $2(13)$ & $3(10)^{\S, \dagger}$ \\
Mitral Regurgitation N, (\%) & $1(7)$ & $2(13)$ & $9(56)^{\S, \dagger}$ \\
Tricuspid Regurgitation N, (\%) & $0(0)$ & $0(0)$ & $12(75)^{\S, \dagger}$ \\
Aortic Regurgitation N, (\%) & $0(0)$ & $4(25)$ \\
\hline
\end{tabular}

$p<0.05 ;{ }^{\circledR} \mathrm{rEF}+\mathrm{dHF}$ versus control, ${ }^{\dagger} \mathrm{rEF}+\mathrm{dHF}$ versus $\mathrm{rEF}$, and ${ }^{\ddagger} \mathrm{rEF}$ versus control. Data represent means $\pm \mathrm{SD}$ unless otherwise indicated.

TABLE 4: Medication usage.

\begin{tabular}{|c|c|c|c|}
\hline \multirow{2}{*}{ Laboratory Test } & \multirow{2}{*}{$\begin{array}{c}\text { Normal Systolic Function } \\
\text { Control }\end{array}$} & \multicolumn{2}{|c|}{ Reduced Systolic Function (Systolic Dysfunction) } \\
\hline & & No Heart Failure & Heart Failure \\
\hline ASA $(\mathrm{N},(\%))$ & $14(88)$ & $11(69)$ & $13(81)$ \\
\hline Beta Blocker (N, (\%)) & $10(63)$ & $15(94)$ & $11(69)$ \\
\hline ACE-inhibitor $(\mathrm{N},(\%))$ & $8(50)$ & $11(69)$ & $11(69)$ \\
\hline Angiotensin Receptor Blocker (N, (\%)) & $1(6)$ & $3(19)$ & $2(13)$ \\
\hline Spironolactone $(\mathrm{N},(\%))$ & $2(13)$ & $9(56)^{\ddagger \ddagger}$ & $8(50)^{\S}$ \\
\hline Diuretic (N, (\%)) & $6(38)^{\S \S}$ & $9(56)$ & $14(88)^{\S}$ \\
\hline Coumadin $(\mathrm{N},(\%))$ & $1(6)$ & $3(19)$ & $4(25)$ \\
\hline Nitrates $(\mathrm{N},(\%))$ & $6(38)$ & $3(19)$ & $3(19)$ \\
\hline Statin $(\mathrm{N},(\%))$ & $14(88)^{\dagger}$ & $14(88)^{\dagger}$ & $9(56)$ \\
\hline Digoxin (N, (\%)) & $0(0)$ & $5(31)^{\ddagger}$ & $4(25)$ \\
\hline Antiarrhythmic (N, (\%)) & $0(0)$ & $2(13)$ & $3(19)$ \\
\hline
\end{tabular}

$p<0.05 ;{ }^{\S} \mathrm{rEF}+\mathrm{HF}$ versus control, ${ }^{\dagger} \mathrm{rEF}+\mathrm{HF}$ versus $\mathrm{rEF}$, and ${ }^{\ddagger} \mathrm{rEF}$ versus control. ${ }^{\S \S} p<0.01 ; \mathrm{rEF}+\mathrm{dHF}$ versus control and ${ }^{\ddagger \neq} \mathrm{rEF}$ versus control. Data represent means \pm SD unless otherwise indicated.

assay ranges for these natriuretic system proteins were corin (linear detectable range 30-1000 pg/ml), neprilysin (linear detection range $0.2-16 \mathrm{ng} / \mathrm{ml}$ ), ANP (detectable range 0$100 \mathrm{ng} / \mathrm{ml}$; linear range $0.1-10 \mathrm{ng} / \mathrm{ml}$ ), and cGMP (linear detectable range $2-500 \mathrm{pmole} / \mathrm{ml}$ ). Plasma samples were diluted 2-10-fold to fit the calibration curves/detectable assay ranges. All other measurements including BNP (Siemens Centaur) were by the VA clinical laboratory. Median corin levels were significantly lower in all patients with $\mathrm{rEF}$, than in controls $(\mathrm{p}<0.05)$. In contrast, median neprilysin levels were significantly higher in all patients with rEF than in controls $(\mathrm{p}<0.01)$. As HF scores worsened, neprilysin levels appeared to increase (Figure 1(a)). In contrast, corin levels were reduced in patients with rEF but did not appear to change with increasing HF score (Figure 1(a)). Patients with $\mathrm{rEF}+\mathrm{dHF}$ had higher BNP levels and HF scores than $\mathrm{rEF}$ alone or control patients (Figure 1(b)), reflecting clinical dHF, as expected. ANP levels rose significantly with increasing HF (Figure 1(c)). In parallel, there was a significant increase in cGMP levels with more severe HF scores (Figure 1(c)). As neprilysin levels rose, log ANP levels also increased, reflecting a positive correlation between the two measures $\left(r_{p}=0.45, p<0.01\right)$. However, there was a negative correlation between log corin and neprilysin levels, indicating that, as corin decreased, neprilysin levels rose $\left(r_{p}=-0.49\right.$, $\mathrm{p}<0.001)$. 


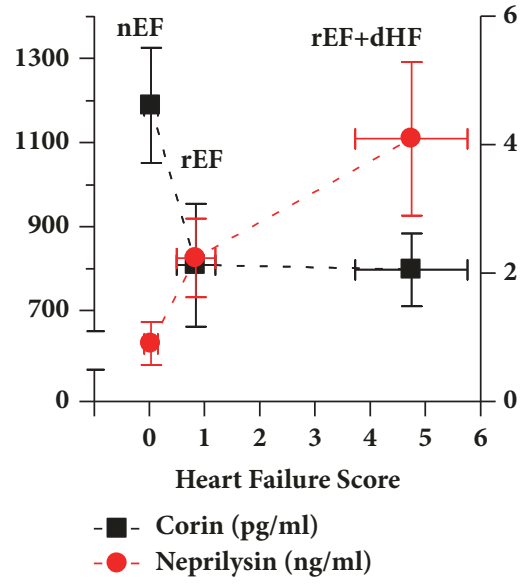

(a)

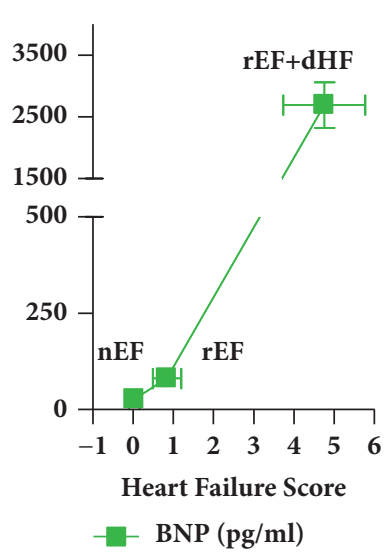

(b)

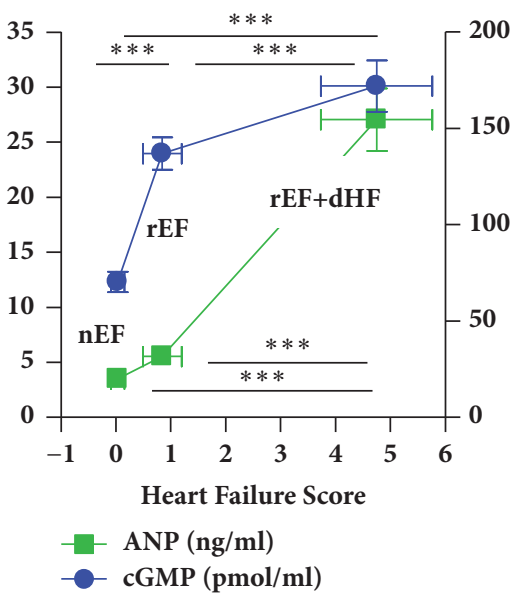

(c)

FIGURE 1: Corin, neprilysin, BNP, ANP, and cGMP levels in patients with normal (nEF) and reduced (rEF) ejection fractions, with and without decompensated (d) HF. (a) Corin and neprilysin plasma levels (mean \pm SE) in patient groups by corresponding HF score (mean \pm SE). (b) BNP levels (mean $\pm \mathrm{SE}$ ) in groups with $\mathrm{nEF}$ (control), rEF, and $\mathrm{rEF}+\mathrm{dHF}$ according to HF score, where dHF is defined by a HF score $\geq 2$ [10]. (c) ANP and cGMP plasma levels (mean \pm SD) in patient groups by HF score (mean \pm SE). $N=48,16$ per group. ${ }^{* * *} p<0.001$, one-way ANOVA.

Recent studies have shown that soluble levels of corin are depressed in patients with $\mathrm{HF}[7,9,13,14]$. Experimental data indicate that cardiac corin expression and plasma levels may fall early in the course of cardiomyopathy, reflecting systolic dysfunction prior to the development of $\mathrm{dHF}$, as indicated by fluid retention and increases in blood levels of ANP [2]. Previous clinical studies have correlated corin levels with functional capacity as assessed by NYHA class, but the present data provide the first evidence in humans, consistent with experimental observations in mice, that depressed plasma corin levels may indicate systolic dysfunction, even in the absence of clinical dHF $[2,13]$. By comparison, levels of neprilysin rose in patients with $\mathrm{rEF}$ and progressively with increasing HF score. Neprilysin showed a similar pattern to ANP and cGMP levels, which significantly increased in parallel with the severity of HF. In contrast, corin levels showed a significant negative correlation with both neprilysin and ANP levels. Since our data are derived from a modest sample of male patients at a single VA hospital, it will be important to confirm the generalizability of these research findings in other studies.

In addition to HF, natriuretic peptide levels are also modulated by body mass index and other conditions such as age, sex, and other illnesses [15]. We found that natriuretic peptide levels were the highest in those with the most severe $\mathrm{HF}$, who also had the lowest BMIs. Although BMI and HF have opposite effects on natriuretic peptide levels, elevated BNP levels in HF patients still are associated with a poor prognosis [15]. The natriuretic peptides are believed to have protective effects in $\mathrm{dHF}$ by opposing the action of the reninangiotensin-aldosterone system [3]. However, the finding that corin levels are low and neprilysin levels are high in patients with rEF may possibly suggest enzymatic downregulation of the natriuretic peptide system; indeed, impaired natriuretic peptide processing has been reported in patients with $\mathrm{HF}[7,16]$. Corin levels are known to be downregulated by an IRE-1-dependent mechanism under conditions of enhanced ER stress [17]; much less appears to be known about the mechanisms that regulated neprilysin expression. Nevertheless, the prognostic significance of low plasma corin levels and high neprilysin levels is similar. A recent study found that low corin levels were associated with $\mathrm{rEF}$, lower NYHA functional status, increased cardiovascular mortality, and major adverse cardiac events [14]. Recent data also show that elevated neprilysin levels are associated with enhanced mortality in hospitalized HF patients [8]. Combined inhibition of the renin-angiotensin system and neprilysin was shown to be beneficial in chronic HF patients [18].

In conclusion, corin plasma levels are diminished in patients with $\mathrm{rEF}$, with or without $\mathrm{dHF}$. In contrast, in rEF patients, plasma immune-reactive ANP, BNP, cGMP, and neprilysin levels are higher in patients with dHF. Low corin and high neprilysin levels would be expected to enzymatically downregulate the natriuretic peptide pathway and may be harmful in HF. Consistent with that notion, low corin and high neprilysin levels are associated with a poor prognosis. Further insights into the regulation and activity of the natriuretic peptide system may enhance prognostic and therapeutic precision in patients with HF, by identifying patient subsets that may benefit from specific therapeutic modulation of the natriuretic pathway.

\section{Data Availability}

The data used to support the findings of this study are available from the corresponding author upon request.

\section{Disclosure}

G. L. Reed is a founder of Translational Sciences. Syed S. Zaidi and Ryan D. Ward are co-first authors. 


\section{Conflicts of Interest}

The authors declare that no conflicts of interest exist.

\section{Acknowledgments}

This work was supported in part by the National Institutes of Health (Grant nos. HL92750 and NS089707 to Guy L. Reed and HL115036 to Inna P. Gladysheva).

\section{References}

[1] A. Bayes-Genis, J. Barallat, and A. M. Richards, "A Test in Context: Neprilysin: Function, Inhibition, and Biomarker," Journal of the American College of Cardiology, vol. 68, no. 6, pp. 639-653, 2016.

[2] R. Tripathi, D. Wang, R. Sullivan, T.-H. M. Fan, I. P. Gladysheva, and G. L. Reed, "Depressed corin levels indicate early systolic dysfunction before increases of atrial natriuretic peptide/B-type natriuretic peptide and heart failure development," Hypertension, vol. 67, no. 2, pp. 362-367, 2016.

[3] D. L. Dries, "Process matters : Emerging concepts underlying impaired natriuretic peptide system function in heart failure," Circulation: Heart Failure, vol. 4, no. 2, pp. 107-110, 2011.

[4] I. P. Gladysheva, D. Wang, R. A. McNamee et al., "Corin overexpression improves cardiac function, heart failure, and survival in mice with dilated cardiomyopathy," Hypertension, vol. 61, no. 2, pp. 327-332, 2013.

[5] D. T. M. Ngo, J. D. Horowitz, and A. L. Sverdlov, "Heart failure: A corin-deficient state?” Hypertension, vol. 61, no. 2, pp. 284285,2013

[6] T. Ichiki, G. Boerrigter, B. K. Huntley et al., "Differential expression of the pro-natriuretic peptide convertases corin and furin in experimental heart failure and atrial fibrosis," American Journal of Physiology-Regulatory, Integrative and Comparative Physiology, vol. 304, no. 2, pp. R102-R109, 2013.

[7] U. N. Ibebuogu, I. P. Gladysheva, A. K. Houng, and G. L. Reed, "Decompensated heart failure is associated with reduced corin levels and decreased cleavage of pro-atrial natriuretic peptide," Circulation: Heart Failure, vol. 4, no. 2, pp. 114-120, 2011.

[8] A. Bayés-Genís, J. Barallat, A. Galán et al., "Soluble neprilysin is predictive of cardiovascular death and heart failure hospitalization in heart failure patients," Journal of the American College of Cardiology, vol. 65, no. 7, pp. 657-665, 2015.

[9] U. N. Ibebuogu, I. P. Gladysheva, and G. L. Reed, "Is heart failure due to impaired clevage and activation of atrial natriuretic peptide?" Journal of the American College of Cardiology, vol. 53, pp. A467-A468, 2009.

[10] R. W. Troughton, C. M. Frampton, T. G. Yandle, E. A. Espiner, M. G. Nicholls, and A. M. Richards, "Treatment of heart failure guided by plasma aminoterminal brain natriuretic peptide $(\mathrm{N}$ BNP) concentrations," The Lancet, vol. 355, no. 9210, pp. 11261130, 2000.

[11] P. A. McKee, W. P. Castelli, P. M. McNamara, and W. B. Kannel, "The natural history of congestive heart failure: the Framingham Study," The New England Journal of Medicine, vol. 285, no. 26, pp. 1441-1446, 1971.

[12] M. Correale, N. Tarantino, R. Petrucci et al., "Liver disease and heart failure: Back and forth," European Journal of Internal Medicine, 2017.
[13] N. Dong, S. Chen, J. Yang et al., "Plasma soluble corin in patients with heart failure," Circulation: Heart Failure, vol. 3, no. 2, pp. 207-211, 2010.

[14] X. Zhou, J.-C. Chen, Y. Liu et al., "Plasma corin as a predictor of cardiovascular events in patients with chronic heart failure," JACC: Heart Failure, vol. 4, no. 8, pp. 664-669, 2016.

[15] A. S. Bhatt, L. B. Cooper, A. P. Ambrosy et al., "Interaction of body mass index on the association between n-terminal-pro-b-type natriuretic peptide and morbidity and mortality in patients with acute heart failure: findings from ASCEND-HF (acute study of clinical effectiveness of nesiritide in decompensated heart failure)," Journal of the American Heart Association, vol. 7, no. 3, Article ID e006740, 2018.

[16] B. K. Huntley, S. M. Sandberg, D. M. Heublein, S. Jeson Sangaralingham, J. C. Burnett, and T. Ichiki, "ProB-type natriuretic peptide-1-108 processing and degradation in human heart failure," Circulation: Heart Failure, vol. 8, no. 1, pp. 89-97, 2015.

[17] R. Lee, B. Xu, J. E. Rame, L. E. Felkin, P. Barton, and D. L. Dries, "Regulated inositol-requiring protein 1-dependent decay as a mechanism of corin RNA and protein deficiency in advanced human systolic heart failure," Journal of the American Heart Association, vol. 3, no. 6, p. e001104, 2014.

[18] J. J. V. McMurray, M. Packer, A. S. Desai et al., "Angiotensinneprilysin inhibition versus enalapril in heart failure," The New England Journal of Medicine, vol. 371, no. 11, pp. 993-1004, 2014. 


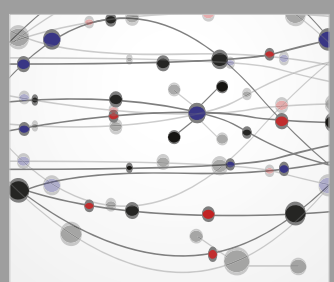

The Scientific World Journal
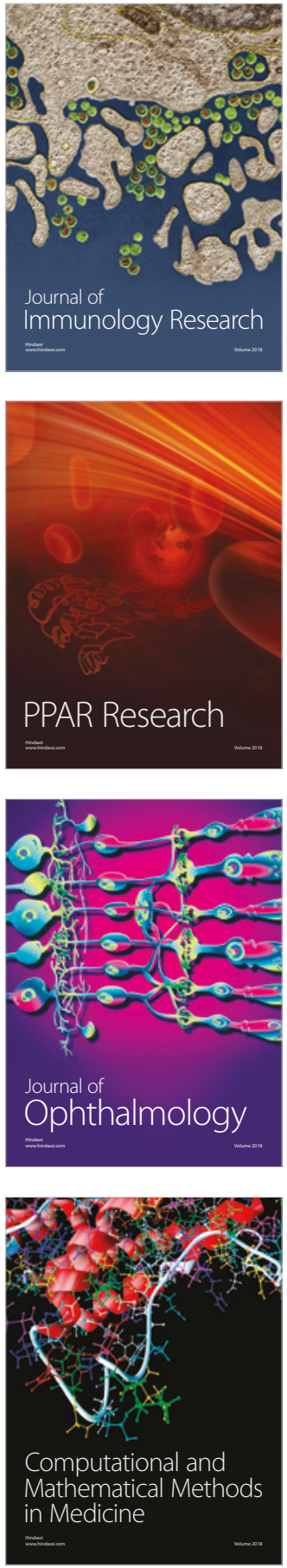

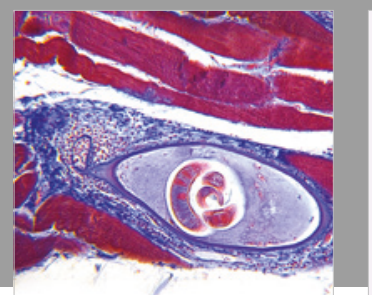

Gastroenterology Research and Practice

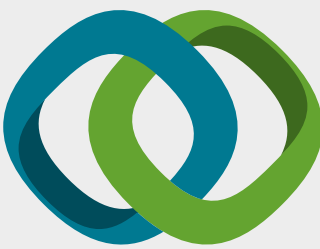

\section{Hindawi}

Submit your manuscripts at

www.hindawi.com
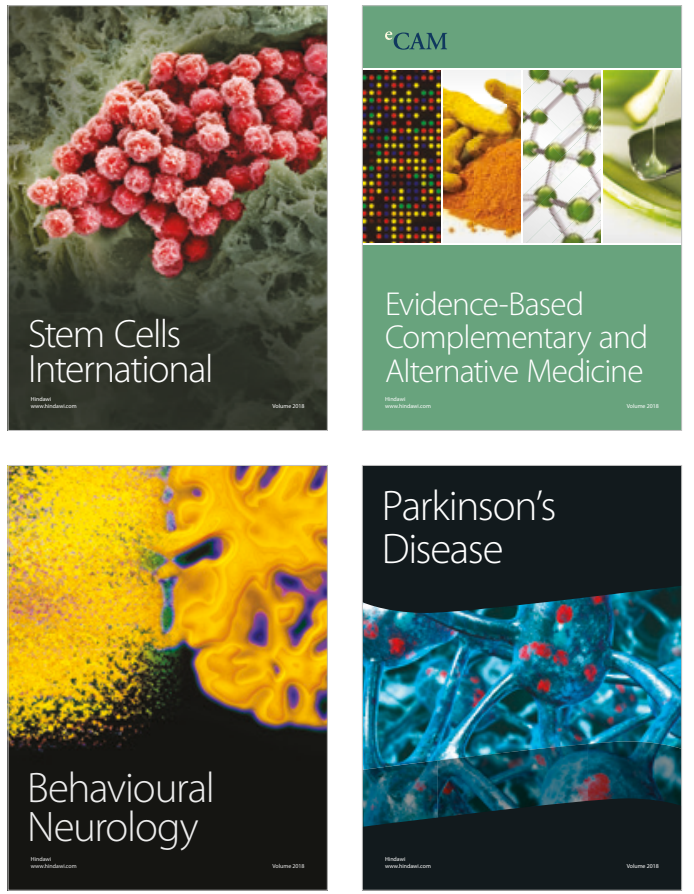

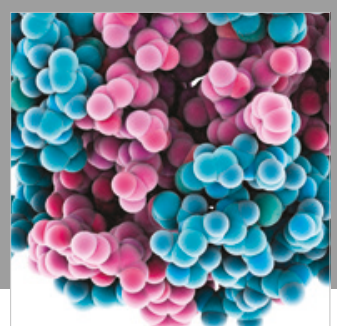

ournal of

Diabetes Research

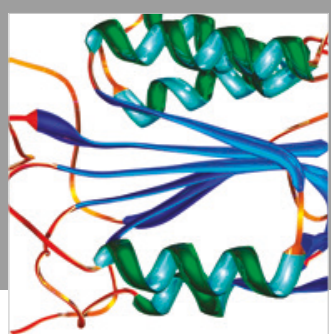

Disease Markers
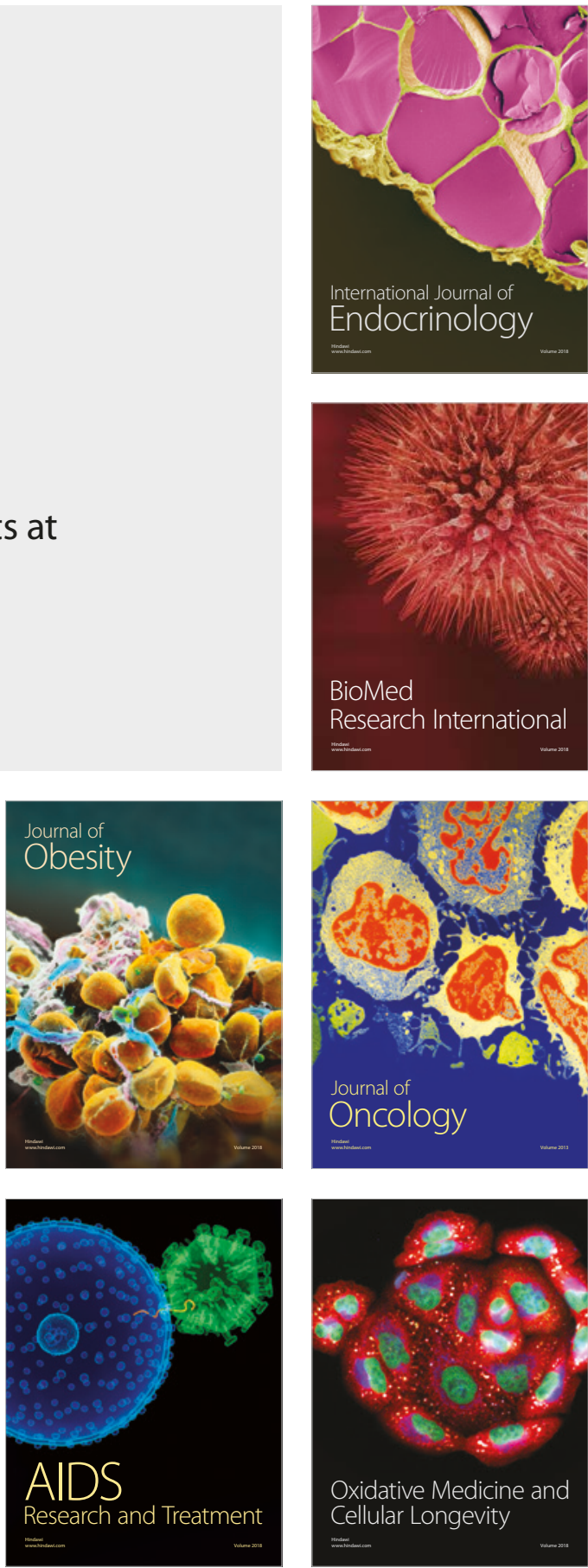